\title{
Tahap Negosiasi dan Memorandum of Understanding (MoU) dalam Penyusunan Kontrak
}

\author{
Putu Devi Erviana1
}

${ }^{1}$ Program Studi Magister (S2) Kenotariatan Fakultas Hukum Universitas Udayana,

E-mail: deviierviana@gmail.com

Info Artikel
Masuk : 28 Oktober 2019
Diterima : 30 Oktober 2019
Terbit : 30 April 2020
Keywords :
Negotiation, Memorandum of
Understanding, Contract
Corresponding Author:
Putu Devi Erviana, E-mail:
deviierviana@gmail.com
10.24843/AC.2020.v05.i01.p11
Kata kunci:
Understanding (MoU),
Kontrak

\begin{abstract}
Indonesia provides an equal opportunity - magnitude by providing a variety of regulations related to capital investment for investors both domestically and from abroad, so it will be born contracts - especially in the field of business. Before becoming a contract final there is a level to be passed that is the negotiation stage and the stage of the Memorandum of Understanding (MoU). In this study aims to provide clarity on the importance of negotiations and the MoU in drafting the contract as a crucial point. The normative legal method used the authors as the basis for this research with the statute approach. Using snow ball technique and card system technique in the collection of its legal materials. It is then processed and analyzed by the technique of description, comparative, evaluating, and argumentation. Finally, the outcome of negotiations is a bargaining process by counseling between one party and the other, with the intention of obtaining an agreement. Countries that embrace the civil law system and the common aw system have adopted negotiations as the beginning of contract drafting, including Indonesia. The outcome of understanding the parties from the negotiations will be documented through a Memorandum of Understanding (MoU). A memorandum of Understanding (MoU) is a simple initial agreement that only contains the subject matter. The memorandum of Understanding (MoU) does not bind the parties and is included in the non legally binding, consequently the party that feels harmed has not been able to make a lawsuit to court.
\end{abstract}

\begin{tabular}{l}
\hline Abstrak \\
\hline Indonesia memberikan peluang yang sebesar - besarnya dengan \\
menyederhanakan berbagai peraturan terkait penanaman modal \\
bagi para investor baik dari dalam negeri maupun dari luar \\
negeri, sehingga akan lahir kontrak - kontrak khususnya di \\
bidang bisnis. Sebelum menjadi sebuah kontrak yang final ada \\
tahap yang harus dilalui yaitu tahap negosiasi dan tahap \\
Memorandum of Understanding (MoU). Dalam penelitian ini \\
bertujuan untuk memberikan kejelasan mengenai pentingnya \\
negosiasi dan MoU dalam penyusunan kontrak sebagai poin \\
yang krusial. Metode hukum normatif digunakan penulis \\
sebagai dasar dilakukannya penelitian ini dengan pendekatan \\
Undang - Undang. Menggunakan teknik bola salju dan teknik \\
sistem kartu dalam pengumpulan bahan hukumnya. Kemudian
\end{tabular}


diolah dan dianalisis dengan teknik mendeskripsi, mengkomparisi, mengevaluasi, serta argumentasi. Akhirnya menemukan hasil yaitu negosiasi merupakan proses tawar menawar dengan cara berunding antara satu pihak dengan pihak yang lain, dengan tujuan mendapatkan kesepakatan. Negara Negara yang menganut sistem Civil Law dan sistem Common Law telah menerapkan negosiasi sebagai awal penyusunan kontrak, termasuk Indonesia. Hasil kesepemahaman para pihak dari negosiasi akan didokumentasikan melalui Memorandum of Understanding (MoU). Memorandum of Understanding (MoU) merupakan perjanjian awal yang sederhana dan hanya memuat hal - hal pokok saja. Memorandum of Understanding (MoU) tidak mengikat para pihak dan termasuk dalam non legally binding, akibatnya pihak yang merasa dirugikan belum dapat melakukan gugatan ke pengadilan.

\section{Pendahuluan}

Berbicara bisnis tidak akan pernah terlepas dari kontrak. Perkembangannya pun didukung dengan berbagai peraturan, seperti hukum kontrak yang tumbuh dengan dinamis, kompleks dan diwarnai dengan problematika yang berkembang di masyarakat. Peningkatan aktifitas bisnis semakin terasa dalam dinamika global ini. Hal yang perlu digaris bawahi dalam bisnis yaitu "setiap langkah bisnis adalah langkah hukum" karena para pihak yang menjalin kerja sama dituangkan dalam bentuk kontrak berdasarkan pertukaran kepentingan. Para pihak yang akan memulai berpijak dalam belantara bisnis harus menyadari dan mengingat bahwa pada dasarnya simpul utama dalam interaksi di dunia bisnis yaitu kontrak sebagai langkah hukum yang menghubungkan kepentingan mereka dengan mengetahui segala konsekuensinya. ${ }^{1}$

Indonesia mengenal hukum perjanjian sebagai bagian dari hukum yang didasarkan pada kesepakatan dari beberapa pihak yang terkait, termasuk pihak dari dalam Negara maupun antar Negara. Itikad baik (Good Faith) merupakan titik dasar yang digunakan oleh Indonesia dalam menyongsong perkembangan bisnis dalam arus globalisasi yang demikian pesat, sehingga tujuan untuk memajukan derajat masyarakat dapat dilakukan melalui perjanjian dengan negara - negara khususnya ASEAN.2

Negosiasi merupakan proses awal yang dilakukan dalam perumusan hubungan kontraktual didasarkan pada ketidaksamaan atau perbedaan kepentingan antara pihak - pihak yang terkait satu dengan yang lainnya. Sehingga melalui negosiasi yang didalamnya terkandung proses saling tawar menawar akan melahirkan bentuk -

\footnotetext{
${ }^{1}$ Agus Yudha Hernoko, (2016). Asas Proporsionalitas Sebagai Landasan Pertukaran Hak dan Kewajiban Para Pihak Dalam Kontrak Komersial. Universitas Airlangga

2 Pratama, G. N. (2016). Kekuatan Hukum Memorandum of Understanding (MoU) Dalam Hukum Perjanjian Indonesia. Veritas et Justitia, 2(2), 424-440.
} 
bentuk dari sebuah kesepakatan yang saling dipertemukan untuk sesuatu kepentingan yang diinginkan. ${ }^{3}$

Hal nyata yang dapat dilihat yaitu sudah barang tentu ketika akan belanja di pasar tradisional maka hal pertama yang dilakukan adalah negosiasi soal harga terhadap barang yang akan dibeli antara pihak pembeli dengan pihak penjual. Namun tidak selalu negosiasi ini terjadi, beda halnya dengan pasar tradisional maka pusat perbelanjaan sudah mematok harga yang baku sehingga pembeli tidak dapat melakukan tawar menawar lagi dengan penjual.

Hal yang menjadi crucial point dalam kontrak bisnis yaitu dalam fase negosiasi dimana dalam perumusannya terdapat pertukaran hak dan juga kewajiban yang akhirnya akan mengikat pihak terkait yang membuat kontrak tersebut dan wajib hukumnya untuk dipenuhi. Yang menjadi tujuan dan juga sasaran dari sebuah negosiasi kontrak yaitu hasil mencapai kata sepakat. Bisa diistilahkan bahwa sepakat ini merupakan sebuah tabir misteri yang lahir dari pertukaran kepentingan para pihak dan harus dibuka melalui negosiasi. Sehingga dari dinamika kontrak tersebut pihak yang terkait dihadapkan pada dua karakteristik negosiasi kontrak yaitu yang bersifat positif dan juga yang bersifat negatif. ${ }^{4}$

Sebagai fase 'crucial point', negosiasi dalam sebuah kontrak, utamanya kontrak bisnis internasional wajib untuk dilakukan. Setiap negara akan melakukannya, tidak terkecuali yang menggunakan sistem civil law ataupun sistem common law. Negara negara tersebut telah menempatkan negosiasi dalam point yang sangat penting untuk melakukan sebuah pengikatan dalam kontrak bisnis nasional ataupun internasional.

Negosiasi adalah hal wajib untuk dilakukan mengingat jika transaksi yang dilakukan dalam skala yang besar. Hal ini untuk memberikan kedudukan mengenai kepastian dan perlindungan terhadap masing - masing pihak. Negosiasi yang dihasilkan dapat berupa perincian yang detail maupun hanya secara sederhana, tergantung dari kepentingan para pihak. Kesepahaman hasil dari negosiasi merupakan wujud dari proses prakontraktual yang dituangkan dalam bentuk tertulis yang dikenal dengan nota kesepahaman yang dalam dunia kontrak bisnis disebut sebagai 'Memorandum of Understanding $(\mathrm{MoU})^{\prime}$.

Hukum kontrak yang berlaku di Indonesia belum memberikan ketentuan khusus yang mengatur mengenai materi muatan maupun substansi yang diatur dalam MoU. Namun berpegang pada prinsip kebebasan berkontrak, maka asas ini merupakan dasar bagi pihak yang terkait untuk bebas menentukan sendiri materi muatannya maupun substansinya sepanjang memenuhi kaidah - kaidah hukum yang telah ada yaitu mematuhi peraturan perundang - undangan yang berlaku, kesusilaan serta

\footnotetext{
${ }^{3}$ Agus Yudha Hernoko. (2014). Hukum Perjanjian Asas Proposionalitas Dalam Kontrak Komersial. Jakarta: Prenadamedia Group, h.1

${ }^{4}$ Ibid. h.148
} 
ketertiban umum. Disamping itu memenuhi syarat - syarat yang sah untuk dibuatnya sebuah perjanjian. Syarat - syarat tersebut di dasarkan dalam Pasal 1320 KUHPerdata. ${ }^{5}$

Memorandum of Understanding (MoU) juga tidak diatur dalam KUHPerdata dan juga tidak ada pengaturan khusus dalam sistem Common Law maupun American Law. Negosiasi dan Memorandum of Understanding (MoU) timbul dalam kebiasaan kebiasaan atau praktik bisnis. Namun demikian dalam proses sebelum kontrak itu disepakati, maka pada umumnya para pihak terlebih dahulu melakukan perundingan - perundingan untuk mencapai kesepakatan mengenai sesuatu hal yang menjadi kepentingan bersama. Hasil yang dicapai dalam negosiasi ini akan menghasilkan sesuatu yang nantinya menjadi elemen - elemen penting dalam perjanjian, yang sebelumnya sudah disusun dalam Memorandum of Understanding (MoU). ${ }^{6}$

Mengingat hukum Indonesia belum mempunyai pengaturan hukum yang secara khusus memberikan pengaturan mengenai Memorandum of Understanding, maka perlu dipertanyakan mengenai kekuatan mengikatnya. Indonesia yang menganut sistem Civil Law menggunakan pola - pola dogmatis. Artinya dalam setiap kerjasama yang dilakukan akan langsung dibuatkan perumusan kehendak para pihak dalam sebuah kontrak atau perjanjian. Sehingga tidak diperlukan lagi sebuah perantara yaitu Memorandum of Understanding dalam mewujudkan sebuah kontrak.

Berbeda halnya dengan sistem Common Law, setiap kontrak yang dibuat harus diperinci secara jelas tentang substansi apa yang ingin diatur dan segala akibat yang kemungkinan akan terjadi nanti setelah dilakukannya penandatanganan perjanjian. Berdasarkan hal tersebut, maka diperlukan sebuah perantara yang mengatur hal - hal umum mengenai substansi - substansi yang akan dituangkan dalam perjanjian berdasarkan kehendak para pihak sebagai hasil dari negosiasi awal untuk memegang komitmen dari masing - masing pihak. Hal ini akan digunakan sebagai dasar nantinya dalam merumuskan kontrak secara rinci.

Indonesia menjadi pusat perhatian dunia saat ini, pemerintah memberikan peluang sebesar - besarnya terhadap investor asing yang masuk. Penyederhanaan peraturan peraturan terkait perijinan pun telah gencar dilakukan oleh pemerintah. Sehingga terjadi pertumbuhan di segala aspek, termasuk di bagian perekonomian untuk menyejahterakan rakyat. Berbagai perjanjian pun telah dilakukan, baik oleh badan hukum publik maupun badan hukum privat. Berdasarkan perkembangan tersebut maka penulis tertarik untuk membahas dengan memberikan kejelasan mengenai kedudukan negosiasi dan Memorandum of Understanding yang menjadi crucial point dalam penyusunan sebuah kontrak.

\section{Metode Penelitian}

Penelitian yang dilakukan ini merupakan penelitian hukum normatif, yang mengonsepkan hukum sebagai susunan tertulis yang memuat kaidah atau norma

\footnotetext{
${ }^{5}$ Wijaya, F. S., Yasa, I. W., Zulaika, E., \& No, J. J. K. (2013). Kajian Yuridis Kekuatan Hukum Memorandum Of Understanding (MoU) Indonesia-Singapura Tentang Kerjasama Kawasan Ekonomi Khusus. Universitas Jember, Jember.

6 Irianto, S. (2016). NEGOSIASI DAN MEMORANDUM OF UNDERSTANDING (MoU) DALAM PENYUSUNAN KONTRAK.
} 
berupa produk hukum peraturan perundang - undangan. Bahan hukum yang digunakan dalam penelitian hukum normatif ini adalah data sekunder. Data sekunder merupakan data yang diperoleh dari bahan kepustakaan atau literatur yang mempunyai hubungannya dengan objek penelitian. Data sekunder terdiri dari bahan hukum primer, bahan hukum sekunder dan bahan hukum tersier.

Bahan hukum primer, yaitu bahan - bahan hukum yang mengikat yang terdiri dari Kitab Undang - Undang Hukum Perdata serta Undang - Undang Nomor 24 Tahun 2000 tentang Perjanjian Internasional. Selanjutnya bahan hukum sekunder merupakan bahan hukum yang memberikan penjelasan mengenai bahan hukum primer, termasuk dalam hasil - hasil penelitian terdahulu juga pendapat - pendapat dari para ahli. Terakhir, bahan hukum tersier dimaksudkan sebagai bahan hukum yang memberikan petunjuk maupun penjelasan terhadap bahan hukum primer dan bahan hukum sekunder, seperti kamus.

Pendekatan Undang - Undang sebagai jenis pendekatan yang digunakan yaitu menganalisis serta mengkaji peraturan perundang - undangan berdasarkan isu hukum terkait. Menggunakan teknik bola salju (snow ball method) dan teknik sistem kartu (card system) sebagai teknik pengumpulan bahan hukumnya. Selanjutnya dari semua bahan hukum yang sudah dikumpulkan akan dianalisis dengan cara mendeskripsi, mengkomparisi, mengevaluasi dan argumentasi untuk menemukan jawaban akhir terhadap isu hukum yang diangkat.

\section{Hasil Dan Pembahasan}

\subsection{Tahap Negosiasi dalam Penyusunan Kontrak}

Dalam praktik dunia bisnis negosiasi merupakan poin penting yang harus dilakukan sebagai fase pra kontraktual untuk berunding secara timbal balik dengan cara mempertemukan pendapat masing - masing pihak sesuai dengan kehendak dan kepentingan nya, sehingga mendapatkan sebuah kesepakatan yang nantinya akan dituangkan dalam sebuah perjanjian. Negosiasi ini merupakan sarana untuk para pihak dapat mempertemukan atau menyatukan pendapat dimana sebelumnya terdapat perbedaan - perbedaan sesuai dengan kepentingan masing - masing untuk mewujudkan sesuatu hal yang nantinya akan saling menguntungkan dan apa yang sama - sama dicari dan diinginkan dapat dicapai dengan itikad baik dan tanpa batasan kehendak tetapi tidak keluar dari kaidah - kaidah hukum yang berlaku baik dalam tatanan hukum nasional maupun hukum internasional.

Menurut Kamus Besar Bahasa Indonesia (KBBI) mengartikan negosiasi sebagai proses tawar menawar antara pihak - pihak yang terkait dalam bentuk kelompok maupun organisasi dengan cara berunding untuk mencapai kesepakatan. Beberapa ahli telah memaparkan definisi mengenai negosiasi. Menurut Lewicki, Barry dan Saunders dalam jurnal yang ditulis oleh Dunn L., negosiasi adalah pertentangan kepentingan antara pihak terkait yang diselesaikan melalui proses negosiasi. ${ }^{7}$ Menurut Salim HS, dalam negosiasi terdapat komunikasi yang dua arah antara para pihak akibat adanya

\footnotetext{
7 Dunn, A. L. (2015). Analisis Strategi Negosiasi Dalam Memasuki Pasar Luar Negeri (Studi Kasus Pada PT. Dan Liris Sukoharjo). Jurnal Administrasi Bisnis, 23(2).
} 
pandangan atau kepentingan yang berbeda terhadap suatu hal dan meletakkan negosiasi sebagai sarana guna mencapai sebuah kesepakatan. ${ }^{8}$

Dikutip dalam bukunya Prof. Dr. Agus Yudha Hernoko9', menurut Garry Goodpaster negosiasi adalah proses bekerja untuk mencapai suatu perjanjian dengan pihak lain, suatu proses interaksi dan komunikasi yang sama dinamis dan variasinya, serta halus bernuansa, sebagaimana keadaan atau yang dapat dicapai orang.

Berdasarkan beberapa pengertian tersebut pada intinya menekankan sebuah proses yang digunakan sebagai sarana atau instrument utama untuk mencapai kesepakatan melalui kepentingan - kepentingan dari para pihak. Dalam proses tersebut terjadi peristiwa tawar menawar yang dikomunikasikan secara terus menerus berdasarkan perbedaan maupun persamaan kepentingan mengenai substansi yang dituangkan dalam Memorandum of Understanding (MoU) dan menjadi kontrak final yang mengikat para pihak, sehingga pada akhirnya tujuan dari negosiasi yaitu kesepakatan dapat terjalin.

Pada prinsipnya dalam penyusunan sebuah kontrak didasarkan pada asas kebebasan berkontrak, masing - masing pihak memiliki kedudukan yang sama. Pada saat negosiasi berlangsung para pihak tidak dibatasi mengenai ruang, waktu, maupun substansi yang akan dimuat dalam kontrak. Penekanan asas ini memberikan ruang kepada para pihak untuk bebas menyampaikan kehendak berdasarkan kepentingan masing - masing sehingga perbedaan kepentingan tersebut dapat disatukan menjadi saling menguntungkan dan dituangkan dalam bentuk tertulis. Pun tidak membatasi tempat dilakukannya negosiasi, dan hal yang akan dinegosiasikan. Tidak melihat nilai besar kecilnya hal yang akan dinegosiasikan. Para pihak bertemu dan memberikan pendapat masing - masing sesuai kehendaknya. Dapat dilihat bahwa dari kebebasan ini memberikan kedudukan yang seimbang terhadap para pihak.

Menurut Jeremy G. Thorn, yang menjadi pertimbangan dasar dan terpenting dalam menegosiasikan sebuah kontrak atau perjanjian adalah kedudukan hukum. Aspek aspek hukum dalam negosiasi perlu dipertimbangkan untuk menghindari sengketa yang kemungkinan akan timbul saat pelaksanaan kontrak. ${ }^{10}$

Negosiasi kontrak memiliki dua sifat, yaitu negosiasi bersifat positif dan negosiasi bersifat negatif. Budiono Kusumohamidjojo menjelaskan bahwa negosiasi kontrak dikatakan bersifat positif apabila kehendak dari para pihak mencapai kesepakatan itu sifatnya kerjasama sedangkan negosiasi bersifat negatif apabila negosiasi dilakukan untuk mencapai perdamaian karena negosiasi tersebut dikehendaki untuk mengakhiri sesuatu hal yang buruk, yaitu perselisihan maupun persengketaan. Selain itu, suasana dialog yang berkembang antar para pihak juga merupakan hal yang dapat menentukan sifat dari negosiasi. ${ }^{11}$

\footnotetext{
${ }^{8}$ Irianto, S. Loc. Cit.

${ }^{9}$ Agus Yudha Harnoko. Op. Cit., h. 152

${ }^{10}$ Wardani, D. K., Hutagalung, B., \& Vidya, M. (2015). Negosiasi dalam Pengadaan Barang dan Jasa oleh Pemerintah sebagai Upaya Mencapai Kesepakatan. Privat Law, (7).

11 Ibid.
} 
Negosiasi dalam sifat positif para pihak dituntut melakukan negosiasi yang adil berdasarkan itikad yang baik sehingga tujuan dari negosiasi tersebut dapat tercapai. Sedangkan pada sifat negatif ini tidak semua hal akan berhasil walaupun menggunakan prinsip itikad baik. Hal ini diakibatkan perbedaan dari para pihak terlalu tajam dan prinsipal. Jika suatu negosiasi diwarnai dengan pendapat - pendapat yang tajam dan prinsipal maka akan sulit untuk mencapai sebuah kesapakatan.

Ada dua corak negosiasi yaitu negosiasi yang dilakukan banyak di dalam lingkungan keluarga maupun antar teman atau sahabat yang tujuan utamanya adalah untuk membina hubungan baik (cultivating), ini disebut sebagai position bargainer (lunak). Corak ini mempunyai kelebihan yaitu kesepakatan yang dihasilkan dalam negosiasi tersebut cepat namun juga mengandung risiko dimana dimungkinkan terjadi pola menang kalah (win - lose). Berbeda halnya dengan corak hard position bargainer (keras), bila para perunding yang bertemu terutama yang sama - sama keras maka akan sangat besar kemungkinan menghasilkan kebuntuan atau dead lock yang diakibatkan oleh tekanan maupun ancaman. ${ }^{12}$ Dari kedua corak ini, lebih efektif jika dipadukan menjadi principled negotiation, yang menerapkan aliran win - win, maksudnya keras dalam permasalahan tetapi lunak terhadap orang (hard on the merits, soft non the people).13

Dalam titik ini permasalahan hukum akan timbul jika pihak yang satu terlalu memberikan kepercayaan penuh dan pihak lain terlalu memberikan harapan dengan janji - janjinya sehingga pihak yang dijanjikan telah terlebih dahulu melakukan perbuatan - perbuatan hukum seperti mempersiapkan tempat usaha, melakukan pinjaman uang, maupun membeli tanah. Padahal pada kenyataannya para pihak ini masih berada pada tahap negosiasi/perundingan atau preliminary negotiation belum mencapai kesepakatan final.14 Pada kenyataan negosiasi yang tidak berjalan lancar sesuai dengan harapan yaitu menjadi sebuah kontrak yang final menemui jalan yang buntu/lock dead atau bisa dikatakan janji - janji yang telah diucapkan oleh salah satu pihak telah ditarik, maka akan mengakibatkan pihak lain yang telah berinvestasi dan telah melakukan perbuatan hukum tersebut akan mengalami kerugian. Permasalahan akan lebih rumit lagi ketika yang diajak berunding tersebut adalah warga Negara asing, karena sistem hukum yang digunakan berbeda.

Berdasarkan ketentuan tersebut maka sebuah penyusunan kontrak haruslah berlandaskan pada asas itikad baik. Walaupun dalam perundingan prinsipnya adalah asas kebebasan berkontrak tetapi tetap berpegang pada asas itikad baik. Hal ini penting karena jika terjadi perbuatan hukum sebelum kontrak final namun salah satu pihak tidak menepati janji - janjinya maka akan mengakibatkan sebuah kerugian pada pihak lain.

Menariknya sistem hukum Indonesia belum mengatur mengenai bagaimana akibat hukum nya jika terdapat pihak mengalami kerugian pada tahap pra kontrak. Indonesia menerapkan bahwa negosiasi belum mengikat para pihak. Sehingga jika

\footnotetext{
${ }^{12}$ Salim HS. (2003). Perkembangan Hukum Kontrak Innominaat di Indonesia. Jakarta: Sinar Grafika, h. 125

${ }^{13}$ Ibid.

14 Suharnoko. (2015). Hukum Perjanjian Teori dan Analisis Kasus Edisi Kedua. Jakarta: Prenada

Media Group, h. 1
} 
terjadi kerugian terhadap salah satu pihak pada tahap negosiasi maka pihak yang dirugikan secara hukum belum bisa melakukan gugatan di pengadilan.

Hakim Indonesia berpandangan bahwa ganti rugi terhadap wanprestasi berdasarkan perjanjian pra kontrak tidak dapat dilakukan atau dimintakan karena bukanlah merupakan perjanjian yang sah. Perkara yang diputus oleh hakim di Indonesia tidak semata hanya melihat dari sebelah sisi, yaitu sisi kepastian hukum saja, tetapi juga dari sisi keadilan. 15

Di beberapa Negara yang menganut sistem common law maupun sistem civil law telah menerapkan negosiasi merupakan perbuatan hukum yang mengikat sehingga para pihak yang melakukan wan prestasi dapat dimintakan ganti rugi. Yang termasuk dalam sistem civil law, seperti negara Jerman, Belanda, maupun Perancis sudah menerapkan bahwa negosiasi telah mengikat pihak yang terkait, sehingga jika salah satu pihak dalam negosiasi telah melakukan perbuatan - perbuatan hukum namun ternyata kesepakatan akhir tidak tercapai dan kontrak pun tidak terwujud maka dapat meminta ganti rugi oleh pihak yang merasa mengalami kerugian yang didasarkan pada asas itikad baik.16

Penerapan negosiasi sebagai perbuatan hukum yang mengikat para pihak sehingga dapat dimintakan ganti rugi kepada pihak yang melakukan wan prestasi dalam sistem common law dapat kita lihat dengan dibuatnya doktrin Promissory Estoppel. Doktrin ini dibuat untuk mengatasi kekakuan atas doktrin consideration. Penerapan doktrin consideration mengakibatkan suatu kontrak tidak dapat dituntut pemenuhannya secara hukum karena alasan yang sifatnya teknis. ${ }^{17}$ Promissory Estopel salah satu doktrin hukum yang mencegah seseorang (promisor) untuk menarik kembali janjinya, dalam hal pihak yang menerima janji (promise) karena kepercayaannya terhadap janji tersebut telah melakukan suatu perbuatan atau tidak berbuat sesuatu, sehingga dia (promisee) akan menderita kerugian jika (promisor) yaitu pihak yang memberi janji diperkenankan untuk menarik janjinya. ${ }^{18}$

Dalam perkembangannya pengadilan Amerika Serikat mengembangkan doktrin promissory estoppel dengan mengikuti putusan pengadilan dalam kasus yang sama sebelumnya. Contoh kasus yang terkenal Hoffman melawan Red owl Stores, (1965) 26 Wis.2d.683,133 NW.2d.267., para pihak merundingkan tentang kemungkinan pemberian franchise dari tergugat suatu perusahaan supermarket yang mengoperasikan took di Chilton dan mengisinya dengan barang - barang dagangan untuk dijual oleh Hoffman, jika Hoffman bersedia menginvestasikan uang sebesar 18.000 US dollar. Karena percaya kepada janji - janji tergugat, maka penggugat (Hoffman) membeli sebuah bangunan di Chilton dan menyewa rumah tempat tinggal untuk dirinya beserta keluarganya di Chilton. Akan tetapi, kemudian tergugat menarik kembali janjinya dan meminta jumlah investasi yang lebih besar dan Hoffman

\footnotetext{
${ }^{15}$ Susetya, I. G. P. H., Diantha, I. M. P., \& Landra, P. T. C. ADAPTASI DOKTRIN PROMISSORY ESTOPPEL DALAM PENYELESAIAN GANTI RUGI PADA TAHAP PRA KONTRAK PADA HUKUM KONTRAK DI INDONESIA. Acta Comitas: Jurnal Hukum Kenotariatan, 3(1), 105-121.

${ }^{16}$ Irianto, S. Loc. Cit.

${ }^{17}$ Suharnoko. Op. Cit. h. 12.

${ }^{18}$ Suharnoko. Op. Cit. h. 13.
} 
tidak sanggup untuk memenuhinya sehingga tidak terjadi kontrak franchise antara mereka. ${ }^{19}$

Berdasarkan doktrin common law yang tradisional, pengadilan tidak dapat menghukum tergugat untuk membayar ganti rugi atas biaya yang telah dikeluarkan oleh Hoffman karena common law tidak mengenal penerapan asas itikad baik dalam proses negosiasi. ${ }^{20}$ Akan tetapi the Wisconsin Supreme Court mengadopsi pandangan hukum kontrak modern dengan mengabaikan syarat kepastian hukum demi mencapai keadilan yang substansial. Bagian yang paling menarik dalam kasus ini adalah pengadilan memberikan penggugat reliance damages berupa ganti rugi atas kerugian yang nyata dan bukan expectation damages yaitu kehilangan keuntungan yang diharapkan. Penggugat tidak menerima expectation damages karena memang belum ada kontrak antara penggugat dan tergugat. ${ }^{21}$

Kekosongan norma yang terjadi dalam sengketa pada tahap negosiasi di Indonesia untuk memberikan keadilan kepada pihak yang dirugikan maka hakim dapat melakukan interpretasi atau penafsiran hukum terhadap putusan - putusan pengadilan di negara lain seperti Amerika Serikat. Hakim dapat mengadopsi putusan pengadilan di negara lain dengan melakukan studi banding dalam sengketa yang sama dan dapat menggunakan doktrin Promissory Estoppel. Sehingga putusan yang dibuat oleh hakim tidak semata dilihat dari sisi kepastian hukum tetapi juga keadilan bagi pihak yang dirugikan.

\subsection{Tahap Memorandum of Understanding dalam Penyusunan Kontrak}

Mencatat atau mendokumentasikan merupakan langkah lanjutan yang dilakukan setelah melakukan negosiasi sebagai hasil dari negosiasi awal yang disebut sebagai Memorandum of Understanding (MoU). Berpegang pada prinsip kebebasan berkontrak pihak yang terkait telah diberikan kebebasan untuk menentukan sendiri materi muatannya maupun substansinya sepanjang memenuhi kaidah - kaidah hukum yang telah ada yaitu mematuhi peraturan perundang - undangan yang berlaku, kesusilaan serta ketertiban umum. Disamping itu memenuhi unsur - unsur syarat sah dibuatnya suatu kontrak. Syarat - syarat ini berdasarkan pada Pasal 1320 KUHPerdata. ${ }^{22}$

Black's Law Dictionary menterjemahkan Memorandum of Understanding dengan membagi definisi menjadi Memorandum dan Understanding. Memorandum is to serve the basis of the future formal contract, yang diterjemahkan menjadi dasar untuk memulai penyusunan kontrak secara formal dimasa mendatang. Sedangkan understanding is an implied agreement resulting from the express term of another agreement, whether written or oral, yang dimaknai pernyataan persetujuan tersirat terhadap persetujuan lain, baik secara tertulis ataupun lisan. Dapat dirumuskan MoU merupakan dasar dalam penyusunan sebuah kontrak di masa akan datang sebagai hasil permufakatan dari para pihak, baik secara tertulis ataupun secara lisan.

\footnotetext{
${ }^{19}$ Suharnoko. Op. Cit. h. 14.

${ }^{20}$ Suharnoko. Op. Cit. h. 14.

${ }^{21}$ Suharnoko. Op. Cit. h. 15.

22 Wijaya, F.S. Loc. Cit.
} 
Munir Fuady memberikan pengertian Memorandum of Understanding (MoU) merupakan sebuah perjanjian yang berisikan hal - hal pokok saja, mengenai detailnya akan diatur dalam perjanjian lain sehingga disebut sebagai perjanjian pendahuluan. Hal yang lain - lain dari MoU ini aspeknya tidak berbeda dengan perjanjian lainnya. ${ }^{23}$

Erman Rajagukguk memberi pandangan bahwa para pihak yang telah saling mengerti dimuat dalam dokumen yang disebut Memorandum of Understanding sebelum dibuatnya perjanjian. Untuk dapat memiliki kekuatan yang mengikat maka inti dari Memorandum of Understanding harus tuangkan ke dalam kontrak. ${ }^{24}$

Penulis menarik kesimpulan dari pengertian - pengertian di atas bahwa MoU merupakan perjanjian pendahuluan yang dijadikan dasar sebagai penyusunan kontrak dimasa yang akan datang. Sebagai perjanjian awal substansinya memuat hal - hal pokok saja, akan dijabarkan secara detail pada kontrak final. Memorandum of Understanding dibuat berdasarkan hasil dari negosiasi yang telah dilakukan oleh pihak terkait.

Memorandum of Understanding merupakan suatu perjanjian yang di dalamnya terdapat perbuatan hukum tentunya terdapat pihak. Pihak inilah yang disebut sebagai subjek hukum. Subjek hukum yang dimaksud dapat berupa badan hukum privat maupun badan hukum publik. Badan hukum privat termasuk Perseroan Terbatas (PT), Yayasan, Koperasi. Sedangkan badan hukum publik termasuk Negara, maupun pemerintah provinsi/kabupaten/kota. Jadi dapat dilihat yang bisa menjadi pihak dalam pembuatan MoU tidak tertutup pada badan hukum privat, tetapi juga mencakup badan hukum publik. Cakupan wilayahnya pun sangat luas termasuk regional, skala nasional maupun internasional.

Tujuan dibuatnya Memorandum of Understanding (MoU) menurut Munir Fuady yaitu:

a. MoU dibuat guna mempermudah melakukan pembatalan perjanjian bilamana belum terdapat kepastian kesepakatan kerjasama akan ditindaklanjuti atau tidak dalam prospek bisnis yang dilakukan.

b. MoU dibuat sebagai ikatan awal dengan jangka waktu sementara sebelum tanda tangan kontrak karena kontrak yang akan ditandatangani masih lama dan negosiasi yang dilakukan pun alot.

c. MoU dibuat dikarenakan masih terdapat keraguan terhadap para pihak sehingga perlu mengambil beberapa waktu untuk berpikir dan memutuskan untuk menandatangani sebuah kontrak.

d. Dalam suatu perusahaan yang membuat dan menandatangani MoU adalah pihak eksekutif teras, untuk perincian dari sebuah perjanjian akan disusun dan

${ }^{23}$ Salim HS, et. al. (2014). Perancangan Kontrak \& Memorandum of Understanding (MoU). Jakarta:

Sinar Grafika, h. 46

24 Ibid. 
dinegosiasikan oleh staf - staf khusus yang posisinya tidak lebih tinggi namun secara teknis menguasai, seperti MoU yang dibuat adalah legal officer. ${ }^{25}$

Ciri - ciri Memorandum of Understanding yaitu:

a. Isi yang ringkas, bahkan sering sekali satu halaman saja;

b. Memuat hal inti saja;

c. Sifatnya hanya sebagai pendahuluan yang nantinya akan dirinci dalam perjanjian lain;

d. Terdapat jangka waktu, misalnya satu bulan, enam bulan, atau setahun. Perjanjian ini bisa batal jika jangka waktu yang ditentukan tersebut tidak dilakukan tindaklanjut dengan perjanjian yang lebih rinci ataupun dapat diperpanjang oleh para pihak;

e. Bentuk dari MoU umumnya dibuat dalam perjanjian di bawah tangan; dan

f. Usai penandatanganan MoU pihak - pihak yang terkait tidak diwajibkan untuk membuat perjanjian yang lebih detail, sebab secara reasonable mungkin saja terdapat alasan - alasan sendiri - sendiri ataupun terdapat rintangan dari para pihak untuk tidak melakukan penandatanganan perjanjian yang lebih rinci tersebut. ${ }^{26}$

Hukum konvensional di Indonesia pada dasarnya tidak mengenal nota kesepahaman atau dikenal dengan sebutan Memorandum of Understanding (MoU) atau juga pra kontrak. Namun dalam segi praktiknya terkhusus dibidang komersial, pihak yang berkaitan telah sering menggunakan MoU. ${ }^{27}$ Praktik Memorandum of Understanding awalnya berasal dari sistem Common Law. Namun seiring dengan perkembangan global sekarang, sudah banyak Negara civil law sebagai sistem hukumnya menggunakan Memorandum of Understanding sebagai tahap sebelum dibuatnya sebuah kontrak, salah satunya Indonesia.

Pengaturan hukum di Indonesia belum memberikan perhatian yang berarti terhadap Memorandum of Understanding ini, terbukti belum terdapat pengaturan khusus yang mengatur secara detail terkait hal tersebut. Padahal melihat situasi sekarang, pemerintah sedang gencar menarik investor datang ke Indonesia untuk melakukan kerjasama dengan menanamkan modalnya pada perusahaan - perusahaan Negara maupun swasta. Berdasarkan pengertian dari Memorandum of Understanding di atas yang mana merupakan sifat perjanjiannya sebagai pendahuluan yang dibuat oleh pihak terkait maka saat ini merujuk pada Pasal 1320 Buku III KUHPerdata. Perjanjian

\footnotetext{
${ }^{25}$ Munir Fuady. (1997). Hukum Bisnis dalam Teori dan Praktik. Bandung: Citra Aditya Bhakti, h. 91.

${ }^{26}$ Ibid.

27 Perbedaan antara Perjanjian dengan MoU. Tersedia di https://www.hukumonline.com/klinik/detail/ulasan/lt514689463d4b2/perbedaan-antaraperjanjian-dengan-mou/ (diakses tanggal 18 September 2019)
} 
yang dibuat berdasarkan pada kesepakatan pihak - pihak terkait telah memenuhi unsur dari syarat perjanjian yang sah yaitu "sepakat mereka yang mengikatkan diri".

Selain itu, dasar yang dapat digunakan dalam MoU yaitu Pasal 1338 Ayat (3) KUHPerdata memberikan ketentuan "semua perjanjian yang dibuat secara sah berlaku sebagai undang - undang bagi mereka yang membuatnya". Memberikan penekanan terhadap kata 'semua' sejalan dengan asas kebebasan berkontrak sebagai suatu kebebasan mutlak diberikan oleh peraturan perundang - undangan dalam hal mengadakan maupun tidak mengadakan sebuah perjanjian dengan siapapun serta tidak terbatas dalam menentukan bentuk maupun substansinya.

Jika ditinjau ciri dari MoU adalah perjanjian yang dibuat secara sederhana yang memuat hal - hal umum, artinya tidak dibuat secara rinci dan dibuat di bawah tangan atau tidak notariil sehingga kekuatan mengikatnya masih menjadi pertanyaan. Merujuk pada Pasal 1338 KUHPerdata penekanan kata 'semua' memberikan makna bahwa MoU mengikat sebagaimana sebuah perjanjian.

Pasal 1320 KUHPerdata mensyaratkan sebuah perjanjian tersebut adalah sah apabila memuat hak dan kewajiban para pihak. Namun berdasarkan ciri dari MoU yang dibuat secara sederhana dan bersifat umum terbatas hanya pada kesepemahaman para pihak saja, maka MoU harus memenuhi hak dan kewajiban tersebut dalam substansinya. Barulah Memorandum of Understanding bisa dikategorikan sebagai perjanjian yang mengikat berdasarkan Pasal 1338 KUHPerdata.

MoU yang belum ada pengaturan khususnya akan memberikan kesempatan bagi pihak terkait untuk melakukan wan prestasi. Namun dapat kita temukan dalam Undang - Undang Nomor 24 Tahun 2000 tentang Perjanjian Internasional. Dalam Pasal 1 huruf a memberikan pengertian perjanjian internasional yang intinya adalah perjanjian tertulis yang melahirkan hak serta kewajiban yang bentuk dan namanya tertentu dan diatur dalam hukum internasional namun terbatas di bidang hukum publik. Dari pengertian tersebut bagian penjelasan umum secara terang disebutkan mengenai Memorandum of Understanding yang secara praktis lazim digunakan dalam perjanjian - perjanjian internasional. Sayangnya Undang - Undang ini hanya mengatur perjanjian badan hukum publik saja, belum mengatur badan hukum privat.

Melihat daya ikat dari Memorandum of Understanding ini, hukum Indonesia belum dapat mengatakan bahwa Memorandum of Understanding mengikat para pihak karena belum ada aturan secara khusus, sehingga Memorandum of Understanding merupakan non legally binding. Akibatnya pihak yang dirugikan belum dapat digugat di pengadilan. Akan menjadi sebuah permasalahan besar apabila perjanjian yang dilakukan adalah perjanjian internasional yang hendak dilakukan bersama dengan pihak asing yang menerapkan bahwa Memorandum of Understanding telah mengikat para pihak. Sehingga jika terjadi wan prestasi dapat dituntut ganti kerugian.

Beberapa Negara berpandangan bahwa Memorandum of Understanding ini hanya memuat komitmen politik dan moral. Jika salah satu pihak melakukan wan prestasi maka ia akan dipandang tidak bermoral dan sulit untuk dipercaya dalam melakukan perjanjian - perjanjian lain dengan pihak ketiga. Dalam tatanan praktis, saat ini Memorandum of Understanding sudah sangat lazim dilakukan sehingga sangat perlu 
diberikan perhatian lebih untuk memberikan kepastian hukum jika terjadi wan prestasi dapat dituntut ganti kerugian dengan melakukan gugatan di pengadilan.

Kekosongan hukum terhadap MoU seharusnya tidak dibiarkan berlarut - larut. Mengingat gencarnya pemerintah menarik investor masuk dan berinvestasi di Indonesia sudah selayaknya urgensi pembuatan pengaturan khusus mengenai MoU dilakukan sehingga dapat memberikan kepastian hukum bagi para pihak yang bersepakat. Hingga saat ini, merujuk pada penjelasan di atas maka MoU yang merupakan perjanjian pendahuluan, pengaturannya tetap tunduk pada ketentuan Pasal 1320 dan Pasal 1338 Ayat (3) KUHPerdata.

Selain itu, bagi para pihak yang merasa dirugikan dapat mengajukan gugatan ke pengadilan, yang mana hakim di Indonesia dapat melakukan konstruksi hukum dengan tidak mengacu pada sistem hukum yang tradisional, tetapi sudah mengacu pada sistem hukum yang modern. Hakim dapat melakukan studi banding dengan putusan - putusan yang dibuat oleh negara - negara yang menganut sistem common law, yaitu yang mengadopsi doktrin Promissory Estoppel. Doktrin ini dapat berlaku selain pada tahap negosiasi juga pada tahap MoU, hal ini dikarenakan keduanya masih berada pada tahap awal dalam penyusunan kontrak. Sehingga bagi pihak yang telah diberikan pengharapan atas janji - janji yang telah diberikan oleh pihak lain yang mana belum terjadi pengikatan yang sah yaitu kontrak final berdasarkan peraturan yang berlaku di Indonesia dan pihak yang menerima pengharapan atas janji - janji tersebut mengalami kerugian mendapat keadilan dengan mengesampingkan sisi kepastian hukum.

\section{Kesimpulan}

Dalam praktik dunia bisnis negosiasi dan Memorandum of Understanding merupakan poin penting yang harus dilakukan sebagai fase pra kontraktual. Negosiasi sebagai bagian dalam proses tawar - menawar antara pihak - pihak terkait yang secara terus menerus berunding hingga mencapai kesepakatan.Tujuannya adalah mendapatkan sebuah kesepakatan yang nantinya akan dituangkan dalam sebuah perjanjian. Sebagai negara yang menerapkan sistem civil law, Indonesia belum mengatur akibat hukum jika salah satu pihak mengalami kerugian dalam fase pra - kontrak. Namun dibeberapa Negara lain dengan sistem civil ataupun common law telah menerapkan negosiasi merupakan suatu perbuatan hukum mengikat sehingga pihak yang wan prestasi dapat dimintakan ganti rugi.

Sedangkan nota kesepahaman atau Memorandum of Understanding (MoU) merupakan perjanjian yang bersifat pendahuluan saja sebagai dasar dalam penyusunan kontrak dimasa yang akan datang. Sebagai perjanjian awal substansinya memuat hal - hal pokok saja, akan dijabarkan secara detail pada kontrak final. Memorandum of Understanding dibuat berdasarkan hasil dari negosiasi yang dirundingkan oleh para pihak terkait. Memorandum of Understanding merupakan non legally binding, sehingga akibatnya pihak yang dirugikan belum dapat digugat di pengadilan. Hingga saat ini belum ada pengaturan mengenai $\mathrm{MoU}$, sehingga pengaturannya tetap tunduk pada Pasal 1320 dan Pasal 1338 Ayat (3) KUHPerdata. 


\section{Daftar Pustaka}

\section{Buku}

Munir Fuady. (1997). Hukum Bisnis dalam Teori dan Praktik. Bandung: Citra Aditya Bhakti.

Salim, HS. (2003). Perkembangan Hukum Kontrak Innominaat di Indonesia. Jakarta: Sinar Grafika.

et. al. (2014). Perancangan Kontrak \& Memorandum of Understanding (MoU). Jakarta: Sinar Grafika.

Suharnoko. (2015). Hukum Perjanjian Teori dan Analisis Kasus Edisi Kedua. Jakarta: Prenada Media Group.

\section{Jurnal}

Dunn, A. L. (2015). Analisis Strategi Negosiasi Dalam Memasuki Pasar Luar Negeri (Studi Kasus Pada PT. Dan Liris Sukoharjo). Jurnal Administrasi Bisnis, 23(2).

Irianto, S. (2016). NEGOSIASI DAN MEMORANDUM OF UNDERSTANDING (MoU) DALAM PENYUSUNAN KONTRAK.

Pratama, G. N. (2016). Kekuatan Hukum Memorandum of Understanding (MoU) Dalam Hukum Perjanjian Indonesia. Veritas et Justitia, 2(2), 424-440.

Susetya, I. G. P. H., Diantha, I. M. P., \& Landra, P. T. C. ADAPTASI DOKTRIN PROMISSORY ESTOPPEL DALAM PENYELESAIAN GANTI RUGI PADA TAHAP PRA KONTRAK PADA HUKUM KONTRAK DI INDONESIA. Acta Comitas: Jurnal Hukum Kenotariatan, 3(1), 105-121.

Wardani, D. K., Hutagalung, B., \& Vidya, M. (2015). Negosiasi dalam Pengadaan Barang dan Jasa oleh Pemerintah sebagai Upaya Mencapai Kesepakatan. Privat Law, (7).

Wijaya, F. S., Yasa, I. W., Zulaika, E., \& No, J. J. K. (2013). Kajian Yuridis Kekuatan Hukum Memorandum Of Understanding (MoU) Indonesia-Singapura Tentang Kerjasama Kawasan Ekonomi Khusus. Universitas Jember, Jember.

\section{Tesis/Disertasi}

Hernoko, Agus Yudha, (2016). Asas Proporsionalitas Sebagai Landasan Pertukaran Hak dan Kewajiban Para Pihak Dalam Kontrak Komersial. Universitas Airlangga

\section{Undang - Undang}

Undang - Undang Nomor 24 Tahun 2000 tentang Perjanjian Internasional. Lembaran Negara Republik Indonesia Tahun 2000 Nomor 185

Kitab Undang - Undang Hukum Perdata

\section{Website}


P-ISSN: 2502-8960, E-ISSN: 2502-7573

Perbedaan antara Perjanjian dengan MoU. Tersedia di

https://www.hukumonline.com/klinik/detail/ulasan/1t514689463d4b2/perbe daan-antara-perjanjian-dengan-mou/ (diakses tanggal 18 September 2019) 